\title{
First report of Geosmithia langdonii and Geosmithia spp. isolated from a decaying elm (Ulmus minor) in Geneva, Switzerland
}

\author{
Martine Hänzi, Bastien Cochard, Romain Chablais, Julien Crovadore, François Lefort $₫$ \\ University of Applied Sciences and Arts Western Switzerland, Geneva Institute for Technology Architecture and \\ Landscape, Institute Land Nature and Environment, Plants and Pathogens Group, 50 route de Presinge, 1254 Jussy, \\ Switzerland, e-mail: francois.lefort@hesge.ch
}

\section{Abstract}

The mortality of a young elm Ulmus minor in 2014 in Geneva prompted a search for the microorganisms potentially involved. Symptoms included foliar chlorosis and wilting followed by defoliation of branches. Wood symptoms included a brown streaking of sap wood and brown stains in trunk and branches. The comparison of the resulting ITS rDNA sequences to the NCBI Nucleotide database allowed to identify 10 different organisms. The genus Geosmithia represented $48 \%$ of the isolates belonging to three species: Geosmithia langdonii (7 isolates) and 2 unknown morphologically and genetically different Geosmithia sp. 1 and sp. 2 (4 isolates). Geosmithia species are very little known ascomycetes, which have been recently shown to be opportunistic pathogens on broadleaved trees and conifers, living as saprobes in galleries of many bark beetle species. In the case described here, Geosmithia langdonii, and the unknown Geosmithia species were found in symptomatic wood while bark beetle galleries were found in close regions of the symptomatic wood. Geosmithia langdonii was the major fungus retrieved from the symptomatic wood and could have contributed, along with other identified fungal species, to a pathogenic complex producing symptoms similar to the ones of the Dutch Elm Disease and led to the dieback of this elm tree. Geosmithia langdonii and 2 yet unknown Geosmithia species (sp. 1 and sp. 2), different from any other reported Geosmithia species are reported from an elm tree in Switzerland for the first time.

\section{KeY WORDS}

Dutch elm disease Geosmithia langdonii, Geosmithia spp., elm, Ulmus minor, endophytes

Dutch elm disease (DED) caused by Ophiostoma ulmi and O. novo-ulmi is a matter of concern for city corporations, using elm trees in urban plantations. The death occurrence of a young elm in Sept. 2014, in Geneva (lat. 46.1984, long. 6.1423) in an urban plantation of several Ulmus minor trees, after a few months of decay symptoms, which appeared end of May 2014 (Fig. 1), prompted a search for the microorganisms potentially involved. Symptoms included foliar chlorosis and wilting followed by defoliation of branches. No symptoms were observed on the other elms trees of this plantation. The tree was felled 2 weeks after death. A large 


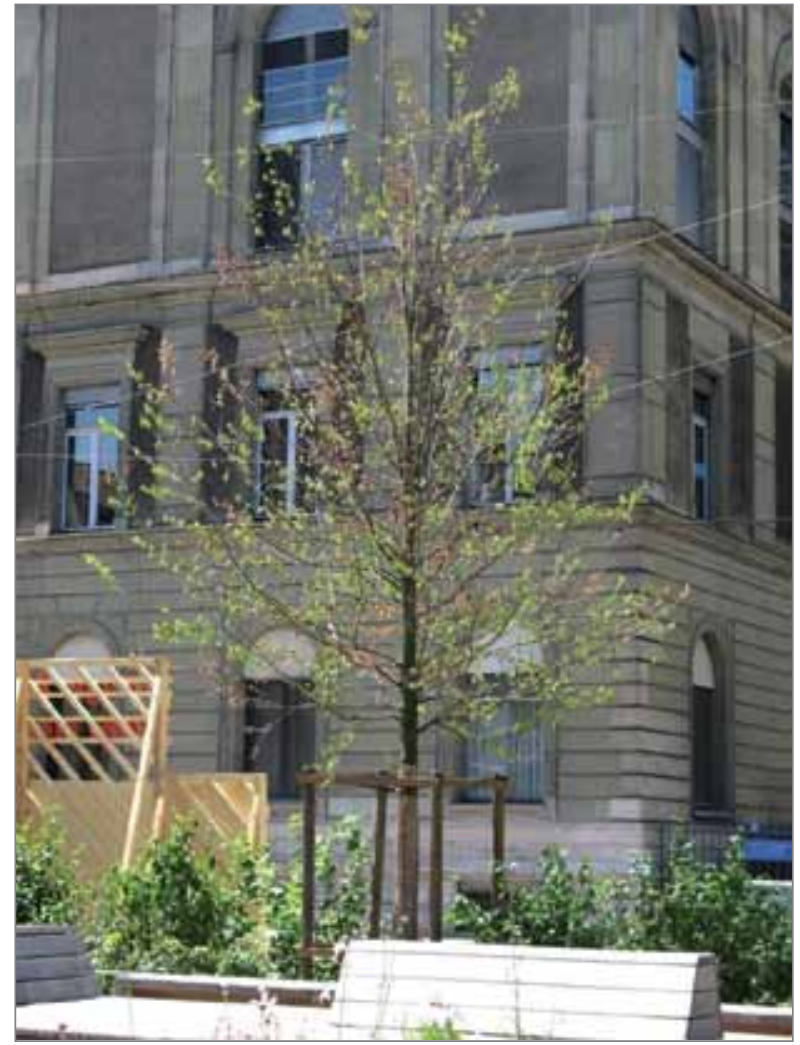

Figure 1. Wilting symptoms on an elm tree on $20^{\text {th }}$ June 2014

branch and a small branch were cut in sections. One section of each was surface disinfected with ethanol $70 \%$ and sampled by coring, with a Pressler hand auger, in symptomatic regions as shown on Figure 2A. Wood symptoms included a brown streaking of sap wood and brown stains in trunk and branches. Three wood cores (5 mm diam.) were cultivated in Petri dishes on Potato Glucose Agar (PGA) medium (Roth AG, Switzerland) plus ampicillin $(50 \mu \mathrm{g} / \mathrm{mL})$ (Roth $\mathrm{AG})$ at room temperature (Fig. 3) and 23 fungal organisms were isolated in pure cultures ( 3 isolates from the trunk section sample, 19 isolates from the large branch section and 1 from the small branch section) on PGA medium. All isolates were observed and classified morphologically with the help of a dissecting microscope.

Subcultures for each morphologically different organism were grown in $50 \mathrm{~mL}$ Potato Glucose Broth (PGB) medium (Roth AG) plus ampicillin $(50 \mu \mathrm{g} / \mathrm{mL})$ in $150 \mathrm{~mL}$ sterile Erlenmeyer flasks, under shaking (100 rpm) at room temperature for one week. Fungal DNA of 14 selected isolates was extracted following a modified protocol adapted from Lefort and Douglas (1999) and assayed in a Nanodrop ND-1000 spectrophotometer (Wilmington, DE, USA) in order to adjust the final DNA concentration to $50 \mathrm{ng} / \mu \mathrm{l}$ in ultrapure water. PCR of the internal transcribed spacer rDNA (ITS15.8S-ITS2) was carried out with the primers pair ITS 4 and ITS 5 (White et al 1990). PCR reactions were performed in a Thermocycler Biometra (Göttingen, Germany) using the Taq polymerase and buffer from Biotools (Madrid, Spain) according to the following programme: initial denaturation for $3 \mathrm{~min}$ at $95^{\circ} \mathrm{C}, 38$ cycles of $60 \mathrm{~s}$ at $95^{\circ} \mathrm{C}, 45 \mathrm{~s}$ at $56^{\circ} \mathrm{C}, 60 \mathrm{~s}$ at $72^{\circ} \mathrm{C}$ terminated by a final elongation of $6 \mathrm{~min}$ at $72^{\circ} \mathrm{C}$. Reactions were carried out in $50 \mu \mathrm{L}$ final volume at a final concentration of $1.5 \mathrm{mM}$ $\mathrm{MgCl}_{2}, 100 \mu \mathrm{M}$ each primer and $0.8 \mathrm{mM}$ dNTPs. After amplification, PCR products quality was assessed by gel electrophoresis in a $1 \%$ agarose gel in $1 \mathrm{x}$ TBE (Tris
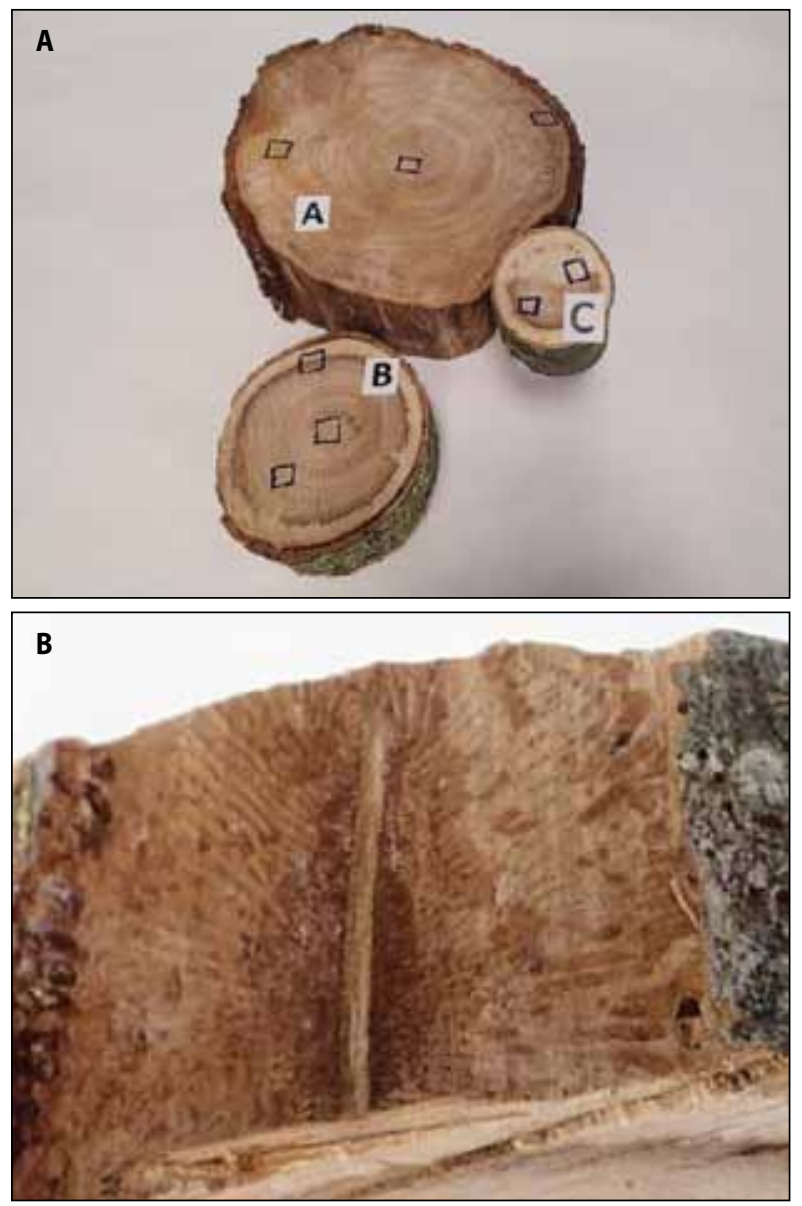

Figure 2. Symptomatic regions sampled on the trunk and branch sections 

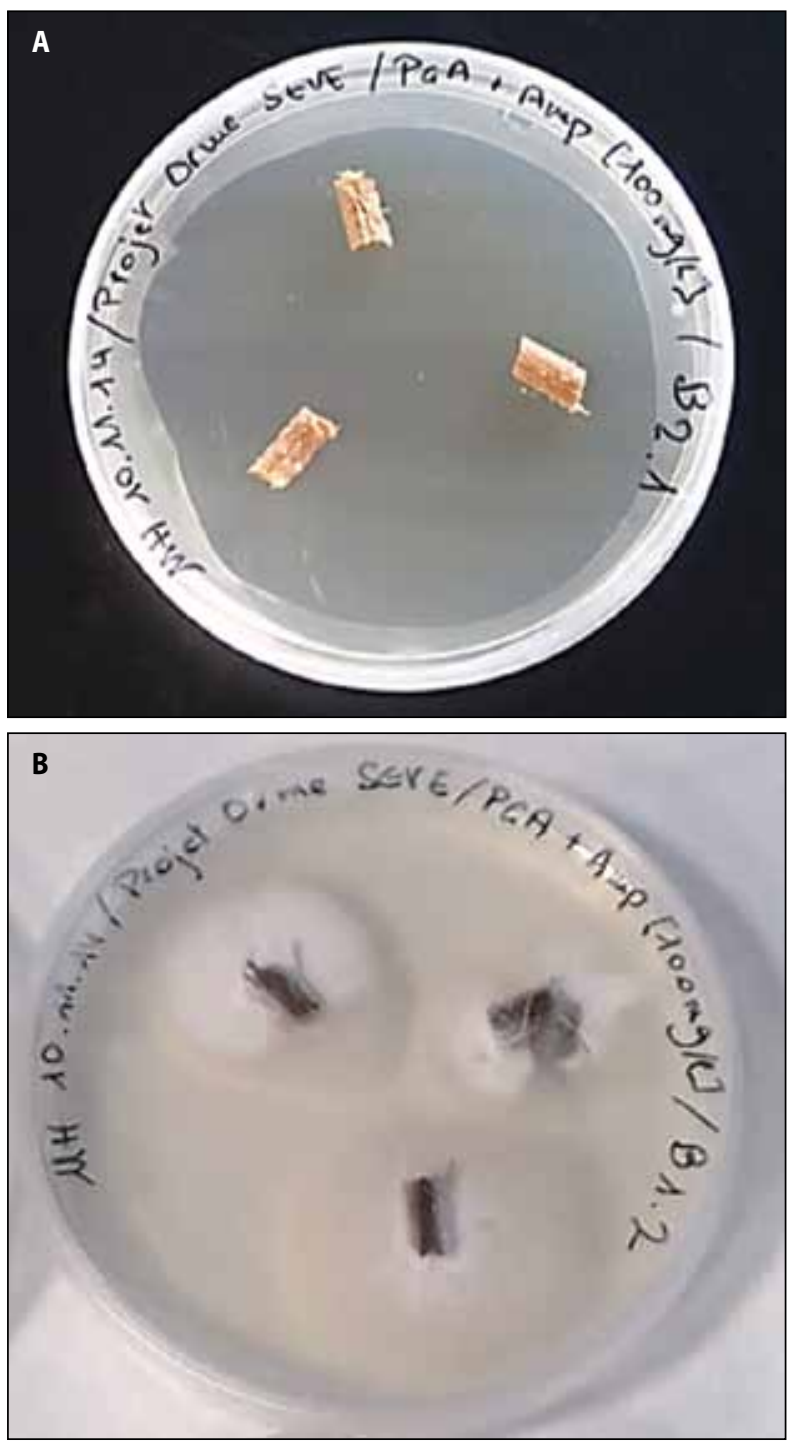

Figure 3. Wood cores on PGA medium (A); Fungal growth on cores on PGA medium (B)

$89 \mathrm{mM}$, boric acid $89 \mathrm{mM}$, EDTA $2 \mathrm{mM}, \mathrm{pH} 8$ ) and revealed by GelRed ${ }^{\mathrm{TM}}$ visualized through a UV transilluminator. PCR products were purified with the Wizard SV Gel and PCR Clean-Up System (Promega Corporation, Madison, USA). The sequencing of PCR products was carried out at Microsynth AG facilities (Balgach, Switzerland) and sequenced finally edited with Finch TV v 1.4.0 (Geospiza Inc., Seattle, WA, USA).

The comparison of the 14 resulting ITS rDNA sequences to the NCBI Nucleotide database (National Center of Biotechnology Information, Bethesda, USA) allowed identifying 10 different organisms, for which sequences have been registered in NCBI under the accessions KP790123-KP790136. The diversity of identified fungi is shown in Table 1. A number of morphologically identical isolates was not sequenced but are reported in Table 1. The genus Geosmithia represented 48\% of the isolates belonging to three species: Geosmithia langdonii (7 isolates) and 2 unknown morphologically and genetically different Geosmithia sp. 1 (2 isolates) and Geosmithia sp. 2 (2 isolates). All these isolates were retrieved from the brown sap wood regions in the small and large branches, but not from the trunk as shown on Table 1. The 3 Geosmithia species were present in the large branch and one Geosmithia sp. was present in the small branch. Three representative isolates, Geosmithia langdonii UASWS1324, Geosmithia sp. 1 UASWS1325 and Geosmithia sp. 2 UASWS1334, have been deposited in the collection DSMZ-Deutsche Sammlung von Mikroorganismen und Zellkulturen (Braunschweig, Germany) under the reference numbers DSM 100090, DSM 100091 and DSM 100360, respectively. The appearance of these three Geosmithia species is shown on Figure 4 and conidia on a conidiophore of G. langdonii are shown on Figure 5. Most noticeably, none of the two fungal species responsible for DED, Ophiostoma ulmi or Ophiostoma novo-ulmi were isolated from symptomatic wood samples. The other identified fungi were potential endophytes such as Cladosporium sphaerospermum, 1 unknown Cladosporium sp., 1 Aspergillus sp., Penicillium brevicompactum and 2 unknown Sordariomycetes sp. genetically close to Aureobasidium sp. or Coniochaeta sp. It is unclear if some of them could be part of a phytopathogenic complex in association with Geosmithia species, able to lead to the observed tree's decay.

Geosmithia species are very little known ascomycetes, which have been recently shown to be opportunistic pathogens on broadleaved trees and conifers, living as saprobes in galleries of many bark beetle species (Jankowiak et al. 2014; Kolařík et al. 2005, 2007). Unknown and undescribed Geosmithia species were already reported on elm (Kolařík et al. 2005, 2007). Among the 50 described Geosmithia species, nine have been found on elm (Kolařík et al. 2008). More recently Pepori et al. (2015) isolated 72 strains of 6 Geosmithia species associated with elms and elm beetles, 3 of these species remaining undescribed. One up to four different species could be retrieved from a single tree. This is 
Table 1. Identification of isolated fungi from wood samples (sample origin, sample type, isolates codes, isolates accession in the collection of the Plants and Pathogens research group, GenBank accession and isolate identities)

\begin{tabular}{|c|c|c|c|c|c|}
\hline Sample origin & $\begin{array}{l}\text { Sample } \\
\text { type }\end{array}$ & $\begin{array}{l}\text { Isolates } \\
\text { codes }\end{array}$ & $\begin{array}{c}\text { Isolates } \\
\text { accessions }\end{array}$ & $\begin{array}{c}\text { GenBank } \\
\text { accessions }\end{array}$ & Isolate identity \\
\hline \multirow{3}{*}{ A Trunk section } & Core A1 & A1.1.1 & UASWS1321 & KP790123 & Cladosporium sphaerospermum \\
\hline & Core A2 & A2.1.1 & UASWS1322 & KP790124 & Aspergillus sp. \\
\hline & Core A3 & A3.1.1 & UASWS1323 & KP790125 & Penicillium brevicompactum \\
\hline \multirow{19}{*}{ B Large branch section } & \multirow{12}{*}{ Core B1 } & $\mathrm{B} 1.1 .1$ & UASWS1324 & KP790126 & Geosmithia langdonii \\
\hline & & $\mathrm{B} 1.1 .2$ & & & Geosmithia langdonii \\
\hline & & B1.1.3 & UASWS1325 & KP790127 & Geosmithia sp. 1 \\
\hline & & B1.1.4 & & & Geosmithia langdonii \\
\hline & & B1.2.1 & UASWS1326 & KP790128 & Geosmithia langdonii \\
\hline & & B1.2.2 & UASWS1327 & KP790129 & Geosmithia sp. 1 \\
\hline & & $\mathrm{B} 1.2 .3 \mathrm{a}$ & UASWS1328 & KP790130 & Geosmithia langdonii \\
\hline & & $\mathrm{B} 1.2 .3 \mathrm{~b}$ & UASWS1329 & KP790131 & Cladosporium sp. \\
\hline & & $\mathrm{B} 1.2 .3 \mathrm{c}$ & & & Geosmithia langdonii \\
\hline & & B1.2.4 & & & Geosmithia sp. 2 \\
\hline & & $\mathrm{B} 1.2 .5$ & UASWS1330 & KP790132 & Cladosporium sp. \\
\hline & & B1.2.6 & UASWS1331 & KP790133 & Geosmithia langdonii \\
\hline & \multirow{7}{*}{ Core B3 } & B3.1.1 & UASWS1332 & KP790134 & Sordariomycetes sp. 1 \\
\hline & & B3.1.2 & & & Sordariomycetes sp. 1 \\
\hline & & B3.1.3 & & & Sordariomycetes sp. 1 \\
\hline & & B3.1.4 & UASWS1333 & KP790135 & Sordariomycetes sp. 2 \\
\hline & & B3.2.1 & & & Sordariomycetes sp. 2 \\
\hline & & B3.2.2 & & & Sordariomycetes sp. 2 \\
\hline & & B3.2.3 & & & Sordariomycetes sp. 2 \\
\hline C Small branch section & Core $\mathrm{C} 2$ & $\mathrm{C} 2.2 .1$ & UASWS1334 & KP790136 & Geosmithia sp. \\
\hline
\end{tabular}

therefore congruent with the observations of three different Geosmithia species reported here in a single tree. The comparison of the ITS DNA sequences of these 3 undescribed species, Geosmithia sp. 2, Geosmithia sp. 5 and Geosmithia sp. 20 (Pepori et al. 2015) to the species Geosmithia sp. 1 and Geosmithia sp. 2 of the present study yielded $91 \%, 91 \%$, and $99 \%$ identity over $83 \%$ of the sequence length, respectively for Geosmithia sp. 1 $93 \%$ identity, over $79 \%$ of the sequence length with each for Geosmithia sp. 2, suggesting that the diversity of Geosmithia species in elms is even greater. In the present case, galleries of bark beetles were observed in the wood of the trunk section (Fig. 2B) but not in the branches. An isolate of an undescribed Geosmithia sp. was found associated once with Dutch elm disease (Scala et al. 2007) in Italy. G. langdonii was also found on elm in a survey of fungi associated to elms (Pepori 2012) and recently identified as a bark-beetle associate and an endophyte of Quercus agrifolia in California (McPherson et al. 2013). Similarly to Ophiostoma ulmi (or O. novo-ulmi) in DED, the pathogenic Geosmithia species have most of the time been shown to be associated with bark beetle species. As stated by Kolařík et al. (2008), Geosmithia species would be dispersed by Phloeophagus bark beetles, with which the association might be very stable and specific, leading to symbiosis and speciation of Geosmithia species in some cases. That was the case for Geosmithia morbida, the agent of the Thousand Cankers Disease of walnut tree species in Europe and the USA (Kolařík et al. 2011; Zerillo et al. 2014; Montecchio et al. 2014), which has been shown to be associated with the bark beetle Pityophtorus juglan- 

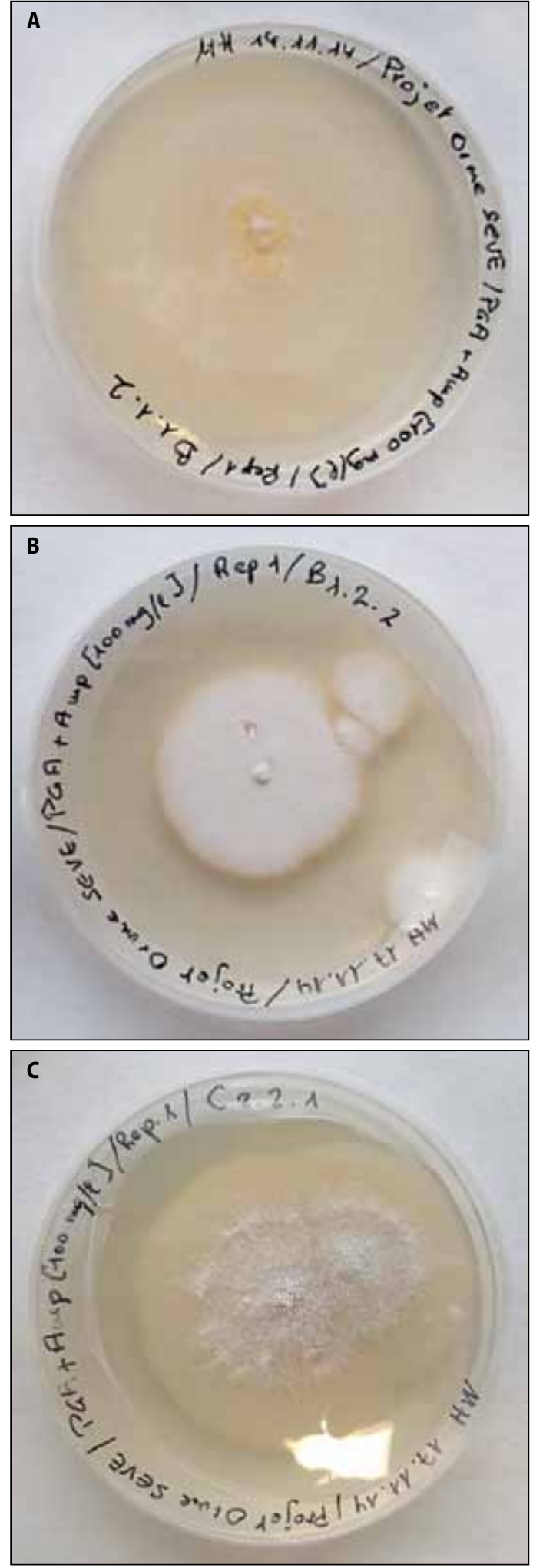

Figure 4. Relative proportions of fungal isolates

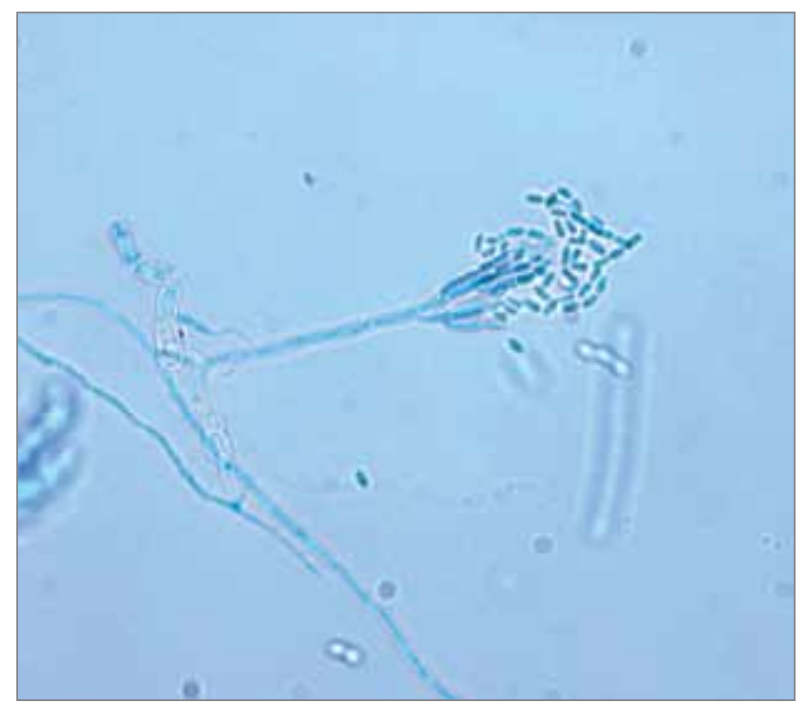

Figure 5. Colonies of Geosmithia langdonii isolate UASWS1324 v, Geosmithia sp. 1 isolate UASWS1325 (B) et Geosmithia sp. 2 isolate UASWS1334 (C) grown on PGA medium

dis. Geosmithia pallida was found associated with the bark beetle Pseudopityophthorus pubipennis in foamy bark canker in Quercus agrifolia in California (Lynch et al. 2014). Other species such as Geosmithia fassatiae, G. langdonii and G. obscura were discovered in association with Scolytus intricatus on several oak species (Kolařík et al. 2005, 2007). Geosmithia langdonii was also described as associated to Platypus cylindrus in the dieback of cork oaks (Quercus suber) in Algeria (Belhoucine et al. 2011). If pathogenicity of Geosmithia langdonii has not yet been proved, its effects on the growth of broadleaved trees and on roots have been demonstrated by Cízková et al. (2005). Geosmithia langdonii has also been often isolated in association with Ophiostoma ulmi and O. novo-ulmi in dying elms affected by DED (Pepori 2012; Bettini et al. 2014; Pepori et al. 2014). Besides these reported cases of plant pathogenicity, one Geosmithia species, Geosmithia argillacea has been shown to cause an invasive mycosis in humans associated to a cystic fibrosis (Giraud et al. 2010; De Ravin et al. 2011).

In the case described here, Geosmithia langdonii, and 2 other unknown Geosmithia species. Geosmithia sp. 1 and sp. 2 were found in symptomatic wood while bark beetle galleries are found in close regions of the symptomatic wood. Geosmithia langdonii was the major fungus retrieved from the symptomatic wood and could 
have taken part to a pathogenic complex contributing to DED symptoms and dieback of this elm tree. The hypothesis that this latter species, or the two unknown Geosmithia species, could not be part of a pathogenic complex cannot be completely withdrawn in absence of inoculations experiments confirming their pathogenicity. It cannot either be excluded that these species could be common endophytes of elm trees.

The main finding of this study is to report, for the first time, Geosmithia langdonii and 2 unknown species of Geosmithia, different from any known species, from an elm tree in Switzerland.

\section{Acknowledgements}

Mrss. Roger Beer and Bertrand Favre from the General Directorate of Agriculture and Nature of the Republic and Canton Geneva and the Geneva City Hall are acknowledged for funding these works.

\section{References}

Belhoucine L., Bouhraoua R.T., Meijer M., EquihuaMartinez A., Pujade-Villar J. 2011. Mycobiota associated with Platypus cylindrus (Coleoptera: Curculionidae, Platypodidae) in cork oak stands of North West Algeria, Africa. African Journal of Microbiology Research, 5 (25), 4411-4423.

Bettini P.P., Frascella A., Kolařík M., Comparini C., Pepori A.L., Santini A., Scala F., Scala A. 2014. Widespread horizontal transfer of the cerato-ulmin gene between Ophiostoma novo-ulmi and Geosmithia species. Fungal Biology, 11, 663-674.

Cízková D., Srůtka P., Kolarík M., Kubátová A., Pazoutová S. 2005. Assessing the pathogenic effect of Fusarium, Geosmithia and Ophiostoma fungi from broad-leaved trees. Folia Microbiology, 50, 59-62.

De Ravin S.S., Challipalli M., Anderson V., Shea Y.R., Marciano B., Hilligoss D., Marquesen M., DeCastro R., Liu Y.-C., Sutton D.A., Wickes B.L., Kammeyer P.L., Sigler L., Sullivan K., Kang E.M., Malech H.L., Holland S.M., Zelazny A.M. 2011. Geosmithia argillacea: An emerging cause of invasive mycosis in human chronic granulomatous disease. Clinical Infectious Diseases, 52 (6), e136e143.

Giraud S., Pihet M., Razafimandimby B., Carrère J., Degand N., Mely M., Favennec L., Dannaoui E., Bouchara J.-P., Calenda A. 2010. Geosmithia argillacea: an emerging pathogen in patients with cystic fibrosis. Journal of Clinical Microbiology, 48 (7), 2381-2386.

Jankowiak R., Kolařík M., Bilańskic P. 2014. Association of Geosmithia fungi (Ascomycota: Hypocreales) with pine and spruce-infesting bark beetles in Poland. Fungal Ecology, 11, 71-79.

Kolařík M., Kubátová A., Cepicka I., Pazoutová S., Srůtka P. 2005. A complex of three new whitespored, sympatric, and host range limited Geosmithia species. Mycological Research, 109, 1323-1336.

Kolařík M., Kostovcík M., Pazoutová S. 2007. Host range and diversity of the genus Geosmithia (Ascomycota: Hypocreales) living in association with bark beetles in the Mediterranean area. Mycological Research, 111, 1298-1310.

Kolařík M., Kubátová A., Hulcr J., Pazoutová S. 2008. Geosmithia fungi are highly diverse and consistent bark beetle associates: evidence from their community structure in temperate Europe. Microbial Ecology, 55, 65-80.

Kolařík M., Freeland M., Utlet C., Tisserat N. 2011. Geosmithia morbida sp. nov., a new phytopathogenic species living in symbiosis with the walnut twig beetle (Pityophthorus juglandis) on Juglans in USA. Mycologia, 103, 325-332.

Lefort F., Douglas G.C. 1999. An efficient micro-method of DNA isolation from mature leaves of four hardwood tree species Acer, Fraxinus, Prunus and Quercus. Annals of Forest Science, 56, 259-263.

Lynch S.C., Wang D.H., Mayorquin J.S., Rugman-Jones P.F., Stouthamer R., Eskalen A. 2014. First Report of Geosmithia pallida causing foamy bark canker, a new disease on coast live oak (Quercus agrifolia), in association with Pseudopityophthorus pubipennis in California. Plant Disease, 98 (9), 1276-1276. McPherson B.A., Erbilgin N., Bonello P., Wood D.L. 2013. Fungal species assemblages associated with Phytophthora ramorum infected coast live oaks following bark and ambrosia beetle colonization in 
northern California. Forest Ecology and Management, 291, 30-42.

Montecchio L., Faccoli M. 2014. First record of Thousand Cankers disease Geosmithia morbida and walnut twig beetle Pityophthorus juglandis on Juglans nigra in Europe. Plant Disease, 98 (5), 696.

Pepori A. 2012. Caratterizzazione e ruolo delle comunità di Geosmithia spp. su olmo. Ph.D. thesis, University of Florence, Florence, Italy.

Pepori A., Luchi N., Kolarik M., Santini A. 2014. Role of fungi of the gen. Geosmithia in relation to the pathosystem elm-elm disease (DED). The IUFRO Incubator 2014, Abstract Volume, UFRO 2014 World Congress.

Pepori A.L., Kolařík M., Bettini P.P., Vettraino A.M., Santini A. 2015. Morphological and molecular characterisation of Geosmithia species on European elms. Fungal Biology, 119 (11), 1063-1074.

Scala A., Comparini C., Carresi L., Tegli S. 2005. The gene encoding cerato-ulmin, an Ophiostoma-produced protein involved in the Dutch elm disease, has been introgressed or horizontally transferred in an unrelated species of the genus Geosmithia. Journal of Plant Pathology, 87 (4), 305.

Scala A., Comparini C., Tegli S., Scala F. 2007. A nonophiostoma fungus express the gene encoding the hydrophobin cerato-ulmin. Journal of Plant Pathology, 89 (2), 233-240.
White T.J., Bruns T., Lee S., Taylor J. 1990. Amplification and direct sequencing of fungal ribosomal genes for phylogenetics. In: PCR protocols, a guide to methods and applications (eds.: M.A. Innis, D.H. Gelfand, J. Shinsky, T.J. White). Academic Press, San Diego.

Zerillo M.M., Ibarra Caballero J., Woeste K., Graves A.D., Hartel C., Pscheidt J.W., Tonos J., Broders K., Cranshaw W., Seybold S.J., Tisserat N. 2014. Population structure of Geosmithia morbida, the causal agent of Thousand Cankers disease of walnut trees in the United States. PLoS ONE, 9 (11), e112847.

http://www.ncbi.nlm.nih.gov/nuccore/814603658

Geosmithia langdonii isolate UASWS1324 18S ribosomal RNA gene, partial sequence; internal transcribed spacer 1 and 5.8S ribosomal RNA gene, complete sequence; and internal transcribed spacer 2 , partial sequence.

http://www.ncbi.nlm.nih.gov/nuccore/814603659

Geosmithia sp. 1 UASWS1325 18S ribosomal RNA gene, partial sequence; internal transcribed spacer 1 and 5.8S ribosomal RNA gene, complete sequence; and internal transcribed spacer 2, partial sequence http://www.ncbi.nlm.nih.gov/nuccore/814603668

Geosmithia sp. 2 UASWS1334 18S ribosomal RNA gene, partial sequence; internal transcribed spacer 1 and 5.8S ribosomal RNA gene, complete sequence; and internal transcribed spacer 2, partial sequence. 